\title{
A new species of Pimelodus La Cépède, 1803 (Siluriformes: Pimelodidae) from rio Ribeira de Iguape basin, Brazil
}

\author{
Frank Raynner V. Ribeiro ${ }^{1}$, Carlos Alberto S. de Lucena ${ }^{2}$ and Osvaldo T. Oyakawa ${ }^{3}$
}

Pimelodus multicratifer, a new species, is described from the rio Ribeira de Iguape basin. The new species differs from the other Pimelodus species by the following features: 26 to 30 gill rakers on the first branchial arch; a combination of three to six rows of dark spots regularly or irregularly scattered on the flanks and several small dark spots irregularly scattered on the dorsal surface of head, supraoccipital process, and sometimes on the dorsal and caudal fins; striated lips; maxillary barbels reaching between posterior tip of the pelvic-fin rays and posterior tip of the middle caudal-fin rays.

Pimelodus multicratifer, espécie nova, é descrita da bacia do rio Ribeira de Iguape. A espécie nova difere das demais espécies de Pimelodus pelas seguintes características: 26 a 30 rastros branquiais sobre o primeiro arco branquial; a combinação de três a seis fileiras de máculas regular ou irregularmente distribuídas sobre os flancos e várias máculas menores irregularmente distribuídas sobre a superfície dorsal da cabeça e processo supraoccipital, e algumas vezes, nas nadadeiras dorsal e caudal; lábios estriados; barbilhões maxilares alcançando a extremidade posterior dos raios da nadadeira pélvica e a extremidade posterior dos raios médios da nadadeira caudal.

Key words: Taxonomy, Catfish, Neotropical region, Coastal drainages.

\section{Introduction}

Pimelodus La Cépède, 1803 is the most speciose genus of the Pimelodidae and has a broad distribution throughout the freshwater drainages of the Neotropical region, ranging from Panama in Central America to Argentina in South America (Lundberg \& Littmann, 2003; Ferraris, 2007). The number of species described in the genus has significantly increased over the last two decades, with the description of thirteen new species, increasing the number of species of the genus from 20 (according to Lundberg \& Littmann, 2003; Ferraris, 2007) to 32. Probably some of these species will be assigned to other genera after future phylogenetic studies.

A hypothesis of monophyly of Pimelodus is lacking, and the species are being included in the genus on the basis of the traditional non-cladistic diagnosis of Eigenmann \& Eigenmann (1890), namely: pterygoid and palatine edentulous; a frontal fontanel not extending posterior to the orbit; a nonspiny broad posterior cleithral process; and first dorsal-fin ray spiny followed by six branched soft rays.
In the last seven years, eight new fish species were described based on recent collection efforts in the rio Ribeira de Iguape basin (e.g., Pereira \& Oyakawa, 2003; Costa et al., 2004; Oyakawa et al., 2005; Takako et al., 2005; Wosiacki \& Oyakawa, 2005; Costa, 2006; Ottoni et al., 2008). The new species described here increases the number of known species of the interesting ichthyofauna of that drainage.

\section{Material and Methods}

Examined specimens belong to American Museum of Natural History, New York (AMNH), Instituto Nacional de Pesquisas da Amazônia, Manaus (INPA), Museu de Ciências e Tecnologia, Pontifícia Universidade Católica do Rio Grande do Sul, Porto Alegre (MCP), Museo de La Plata, La Plata (MLP), Field Museum of Natural History, Chicago (FMNH), Museu de Zoologia da Universidade de São Paulo, São Paulo (MZUSP), Naturhistorisches Museum, Wien (NMW), and Rijksmuseum van Natuurlijke Historie, Leiden (RMNH).

\footnotetext{
${ }^{1}$ Programa de Coleções e Acervos Científicos, Instituto Nacional de Pesquisas da Amazônia. Caixa Postal 478, 69011-970 Manaus, AM, Brazil. fraynner@yahoo.com.br

${ }^{2}$ Setor de Ictiologia, Museu de Ciências e Tecnologia, Pontifícia Universidade Católica do Rio Grande do Sul. Av. Ipiranga 6681, 90619-900, Porto Alegre, RS, Brazil. lucena@pucrs.br

${ }^{3}$ Museu de Zoologia da Universidade de São Paulo. Caixa Postal 42494, 04218-970 São Paulo, SP, Brazil. oyakawa@usp.br
} 
The measurements are straight-line distances taken point-to-point with digital calipers to $0.1 \mathrm{~mm}$, and made on the left side of the fish whenever possible. Measurements and counts followed Lundberg \& McDade (1986) and Lundberg et al. (1991) with the modifications of Lundberg \& Parisi (2002) and Ribeiro \& Lucena (2006). All measurements are expressed as percents of standard length (SL), except subunits of the head, which are expressed as percents of head length (HL).

All rudimentary fin rays were included in the counts. The two posterior-most anal-fin rays, which are inserted at same base, were counted as a single element. Gill rakers were counted on the first branchial arch (epibranchial and ceratobranchial). Vertebral counts included the five elements of the Weberian complex. The first caudal vertebra is that with hemal spine. The compound caudal vertebra (PU1+U1) was counted as a single element. Osteological preparations were cleared and stained (c\&s) for cartilage and bone using the method of Taylor \& van Dyke (1985). Two dry skeletal (SK) specimens and two radiographs (XR) were used for vertebral counts.

The types of Pimelodus brevis and Pimelodus garciabarrigai are missing, and thus comparative analyses were according to Marini et al. (1933) and Dahl (1961), respectively.

In the list of comparative material examined, the collections acronomys and catalog number are followed by the total number of specimens in that lot, range of standard length, $\mathrm{PH}$ - photograph, c\&s (cleared and double stained) and collecting data.

\section{Results}

\section{Pimelodus multicratifer, new species} Figs. 1 and 2

Pimelodus maculatus. -Oyakawa et al., 2006: 117 (citation, figure).

Holotype. MZUSP 91287, 198.0 mm SL, São Paulo, confluence of the rios Pariquera and Pariquera-Mirim, near mouth to the rio Ribeira de Iguape, Pariquera-Açú, ca. 24³7'58'S 4744'11'”, 14 Jun 2001, O. T. Oyakawa, A. Akama, J. C. Nolasco \& A. C. Paixão.

Paratypes. Brazil. São Paulo: rio Ribeira de Iguape basin: MZUSP 70428, 5, 188.3-212.5 mm SL, collected with holotype. INPA 33949, 2 XR, 139.8 and 149.7 mm SL; MCP 44408, 3, 121.5$148.5 \mathrm{~mm}$ SL; MZUSP 37995, 2, 116.9 and $133.8 \mathrm{~mm} \mathrm{SL}, 1 \mathrm{SK}$ $116.9 \mathrm{~mm} \mathrm{SL}$, rio Turvo, $14 \mathrm{~km}$ from Barra do Turvo, $c a .24^{\circ} 42^{\prime} \mathrm{S}$ 4835'W, 22 Jul 1987, O. T. Oyakawa. MCP 14910, 1, 100.7 mm SL, rio Ribeira de Iguape, near mouth of the rio Iporanga, $24^{\circ} 37^{\prime} \mathrm{S}$ 48³7'W, 29 Apr 1990, R. E. Reis \& G. Skuk. MZUSP 2265, 4, 107.0-130.8 mm SL, ribeirão Poço Grande, Juquiá, ca. 2515'14.8'S 47³7'12.6”W, 1898, E. Garbe. MZUSP 45171, 1, $126.8 \mathrm{~mm}$ SL, Eldorado, rio Batatal, ca. 24 35'26.3"S 48¹6'23.9'W, 2 Mar 1993, M. Damato. MZUSP 45208, 1, 139.1 mm SL; Eldorado, rio Pilões, ca. 243''26"S 48¹6'23"'W, 5 Mar 1993, M. Damato. MZUSP 45465, 2, 118.6 and $185.5 \mathrm{~mm} \mathrm{SL}$, same locality and collector, 6 Mar 1993. MZUSP 51957, 1, 125.3 $\mathrm{mm}$ SL, Iporanga, rio Ribeira de Iguape, near mouth of the rio Betari, 21 Aug 1996, S. Buck. MZUSP 55492, 2, 145.9 and 211.1

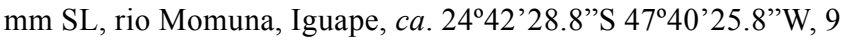
Oct 1995, M. R. Santos. MZUSP 58711, 1, $130.0 \mathrm{~mm} \mathrm{SL}$, rio Pilões, Iporanga, ca. 24³3'16”S 48²5'31'W, 12 Oct 1995, M. R. Santos. MZUSP 58894, 4, 129.0-143.2 mm SL, rio Pardo, Barra do Turvo, ca. 2448'10'"S 48³3'08'”W, 25 Jan 1995, M. R. Santos \& M. Morato. MZUSP 60072, 1, $144.4 \mathrm{~mm} \mathrm{SL}$, same locality, 23 Mar 2000, O. T. Oyakawa et al. MZUSP 73872, 2, 134.5 and 138.4 mm SL, rio Catas Altas, Ribeira, ca. 24³6’32”S 4904'46”W, 14 Oct 1995, M. R. Santos \& M. Morato. MZUSP 84722, 1, 198.8 mm SL, Barro Branco, Ilha Comprida, ca. 2450'17'S 4741'46”'W, 17 Feb 2000, R. Silva.

Additional material (non-types). All from Brazil, State of São Paulo, Municipality of Iguape: MZUSP 55479, 2, 231.7 and $315.2 \mathrm{~mm} \mathrm{SL}$, rio Una da Aldeia, $300 \mathrm{~m}$ above mouth of rio Una da Aldeia, 9 Oct 1995, M. R. Santos \& C. E. Espírito Santo. MZUSP 62886, 2, 218.4 and $227.5 \mathrm{~mm}$ SL, rio Una do Prelado, Estação Ecológica Juréia-Itatins, 26 Jun 2000, M. Rodrigues.

Diagnosis. Pimelodus multicratifer differs from $P$. absconditus Azpelicueta, P. albofasciatus Mees, $P$. atrobrunneus Vidal \& Lucena, $P$. blochii Valenciennes, $P$. britskii Garavello \& Shibatta, P. fur (Lütken), P. halisodous Ribeiro, Lucena \& Lucinda, $P$. jivaro Eigenmann \& Pearson, $P$. joannis Ribeiro, Lucena \& Lucinda, $P$. luciae Rocha \& Ribeiro, P. maculatus La Cépède, $P$. microstoma Steindachner, $P$. ornatus Kner, P. ortmanni Haseman, P. pantaneiro SouzaFilho \& Shibatta, $P$. paranaensis Britski \& Langeani, $P$. pictus Steindachner, P. pintado Azpelicueta, Lundberg \& Loureiro, P. platicirris Borodin, P. pohli Ribeiro \& Lucena, P. stewarti Ribeiro, Lucena \& Lucinda, and $P$. tetramerus Ribeiro \& Lucena by the number of gill rakers on the first branchial arch (26-30 vs. 18-27).

The possession of three to six rows of dark spots, regular or irregularly, scattered on sides of trunk and several small dark spots irregularly scattered on the dorsal surface of head and supraoccipital process, distinguishes Pimelodus multicratifer from P. altissimus Eigenmann \& Pearson, $P$. argenteus Perugia, $P$. atrobrunneus, $P$. blochii, $P$. brevis Marini, Nichols \& La Monte, $P$. halisodous, $P$. jivaro, $P$. joannis, and $P$. stewarti, which have an uniform color pattern, without spots on sides of the trunk and dorsal surface of head and supraoccipital process, and from $P$. albicans (Valenciennes), P. albofasciatus, $P$. ornatus, and $P$. tetramerus, which have stripes or band along the sides of trunk. Also, the possession of spots on the dorsal surface of head and supraoccipital process distinguishes $P$. multicratifer from $P$. absconditus, $P$. britskii, $P$. coprophagus Schultz, $P$. fur, $P$. garciabarrigai Dahl, $P$. grosskopfii Steindachner, $P$. microstoma, P. mysteriosus Azpelicueta, P. navarroi Schultz, P. paranaensis, P. pictus, P. pohli, and P. punctatus (Meek \& Hildebrand). 


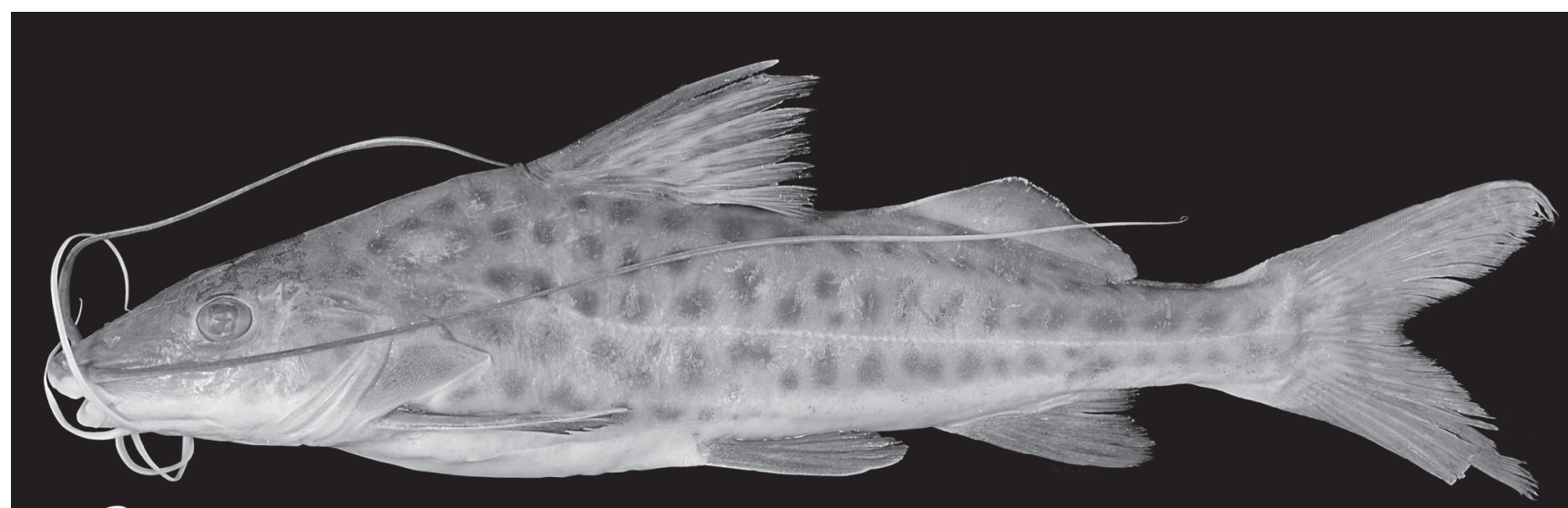

a
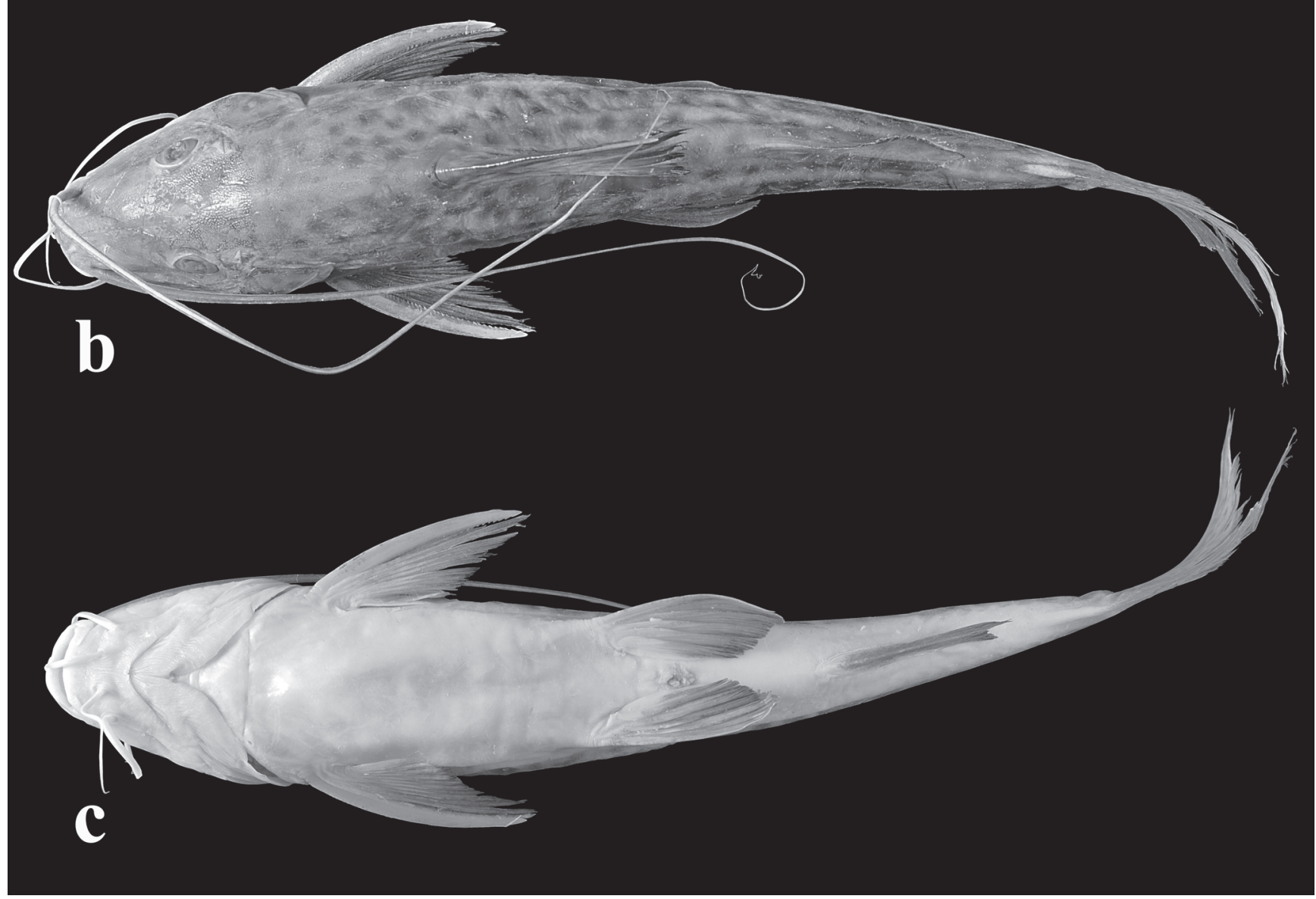

Fig. 1. Pimelodus multicratifer, holotype, MZUSP 91287, 198.0 mm SL, Brazil, São Paulo State, Pariquera-Açú, confluence of rios Pariquera and Pariquera-Mirim, near mouth of the rio Ribeira de Iguape, in lateral (a), dorsal (b), and ventral (c) views.

Pimelodus multicratifer has a similar color pattern to $P$. maculatus, $P$. ortmanni, $P$. pintado, P. platicirris, $P$. mysteriorus, $P$. pantaneiro, and P. luciae. Pimelodus multicratifer differ further from $P$. maculatus by the shorter predorsal distance (40.1-43.0 vs. 43.3-47.3\% of SL), shorter head (27.1-28.9vs. 29.3-33.1\% of SL), smaller caudal peduncle depth (7.6-9.2 vs. 9.8-11.6\% of SL), and shorter adipose-fin base (20.9-23.4 vs. 24.6-27.6\% of SL). Pimelodus multicratifer differ further from $P$. ortmanni by longer predorsal distance
(40.1-43.0 vs. 36.8-39.8\% of SL); shorter adipose-fin base (20.923.4 vs. $24.7-27.0 \%$ of SL); and longer pectoral-spine (18.123.2 vs. 16.3-18.5\% of SL). Pimelodus multicratifer differs further from $P$. pintado by having pectoral, pelvic and anal fins without spots ( $v s$. often present); and lower total number of vertebrae (40 vs. 41 or 42). Pimelodus multicratifer differ further from P. platicirris by shorter head (27.1-28.9 vs. 29.2$32.2 \%$ of SL) and smaller caudal peduncle depth (7.6-9.2 vs. $9.7-11.3 \%$ of SL). Pimelodus multicratifer differ further from 
P. mysteriosus by the striated lips; maxillary barbels shorter, reaching between the end of the pelvic-fin and middle caudalfin rays ( $v s$. maxillary barbels reaching the tip of caudal-fin lobes). Pimelodus multicratifer differ further from $P$. pantaneiro by the smaller body depth (21.3-26.4 vs. 26.9-35.0\% of SL) and by the supraoccipital process width about half its length (vs. approximately as long as its length). Pimelodus multicratifer differ further from $P$. luciae by having the posterior nostril closer to anterior nostril than to anterior margin of orbit ( $v s$. posterior nostril closer to anterior margin of orbit than to anterior nostril).

Description. Morphometric data in Table 1. Body deeper than wide; relatively elongated. Dorsal profile of body slightly convex to straight from snout tip to dorsal-fin origin; straight from this point to adipose-fin origin, gently sloping to beginning of caudal peduncle. Ventral profile of body slightly convex from posterior region of isthmus to anal-fin origin; rising along anal fin. Ventral profile of head straight from the snout tip to anterior region of isthmus. Caudal peduncle relatively long; dorsal and ventral profiles of caudal peduncle slightly concave. Head covered by thin skin. Skull roof ornamented with numerous small osseous granulations, more visible in larger specimens. Snout relatively long. Mouth wide, subterminal, opening anteroventrally; its margins curved in ventral view when closed and exposing premaxillary tooth rows; upper lip thick, not very developed, fleshy and striated. Internarial length shorter than internarial posterior width; anterior nostril with fleshy rim slightly raised posteriorly; posterior nostril thin, fleshy rim anteriorly elevated. Anterior cranial fontanel triangular in dorsal view, open from mesethmoid to frontals, and terminating before vertical through posterior margin of eye. Posterior cranial fontanel completely closed. Premaxillary tooth patch short, broad, rectangular and transversely elongated; each premaxilla with 11-14 irregular rows of conical and slender teeth $($ mode $=12 ; \mathrm{n}=12)$. Dentary with $8-10$ tooth rows (mode $=9 ; \mathrm{n}=12$ ). Vomerine teeth absent. Pterygoid tooth patch absent. Eye large, elliptical, with margin completely free and laterodorsally located on head; horizontal orbital diameter greater than interorbital distance in specimens smaller than $140.0 \mathrm{~mm} \mathrm{SL}$; horizontal orbital diameter always greater than vertical diameter. Supraoccipital process wide, reaching anterior nuchal plate; dorsal surface ornamented with numerous small granulations; sides of supraoccipital process tapering posteriorly; rounded in its posterior tip, covered by thin band of opaque hyaline skin. Anterior and middle nuchal plates ornamented with tuberculated ridges. Gill membranes free, diverging just behind gular fold apex and supported by 8 branchiostegal rays $(\mathrm{n}=2)$. Gill rakers well ossified, long, sharp and slender; rakers on first branchial arch 26-30 (mode $=27 ; n=26) ; 6-10$ on epibranchial $($ mode $=8), 19-22$ on ceratobranchial $($ mode $=$ 19). Three pairs of barbels. Maxillary barbel inserted at vertical through anterior edge of lower jaw; its tip reaching between posterior edge of pelvic fin and middle rays of
Table 1. Morphometric data of Pimelodus multicratifer. Range includes the holotype $(\mathrm{H})$.

\begin{tabular}{|c|c|c|c|c|c|}
\hline Measurements & $\mathrm{H}$ & $\mathrm{n}$ & Low & High & Mean \\
\hline Standard length (mm) & 198.0 & 22 & 107.0 & 212.5 & 143.3 \\
\hline \multicolumn{6}{|c|}{ Percents of Standard length } \\
\hline Predorsal length & 42.2 & 22 & 40.1 & 43.0 & 41.6 \\
\hline Preanal length & 74.5 & 22 & 72.3 & 76.3 & 74.6 \\
\hline Head length & 28.3 & 22 & 27.1 & 28.9 & 28.0 \\
\hline Caudal peduncle length & 14.2 & 22 & 13.5 & 16.9 & 15.4 \\
\hline Caudal peduncle depth & 8.5 & 22 & 7.6 & 9.2 & 8.6 \\
\hline Adipose-fin length & 22.7 & 22 & 20.9 & 23.4 & 21.9 \\
\hline Adipose-fin height & 5.1 & 22 & 4.5 & 5.9 & 5.1 \\
\hline $\begin{array}{l}\text { End of dorsal-fin base to } \\
\text { origin of adipose-fin distance }\end{array}$ & 14.2 & 22 & 11.0 & 16.7 & 14.9 \\
\hline Anal-fin base & 13.4 & 22 & 10.9 & 14.2 & 12.2 \\
\hline Anal-fin length & 16.2 & 22 & 13.9 & 16.2 & 15.0 \\
\hline Pelvic-fin length & 16.5 & 22 & 14.1 & 16.9 & 15.4 \\
\hline Dorsal-fin length & 22.5 & 21 & 20.5 & 24.5 & 22.2 \\
\hline $\begin{array}{l}\text { Urogenital papilla to } \\
\text { anal-fin base origin distance }\end{array}$ & 11.7 & 22 & 8.5 & 12.7 & 11.2 \\
\hline Dorsal-spine length & 22.7 & 21 & 19.6 & 23.9 & 21.6 \\
\hline Pectoral-spine length & 21.3 & 15 & 18.1 & 23.2 & 20.1 \\
\hline Body depth & 25.7 & 22 & 21.3 & 26.4 & 23.7 \\
\hline Body width & 18.8 & 22 & 16.6 & 19.6 & 18.2 \\
\hline Cleithral posterior process length & 13.1 & 22 & 11.8 & 14.0 & 12.6 \\
\hline \multicolumn{6}{|c|}{ Percents of Head length } \\
\hline Head depth & 65.0 & 22 & 58.8 & 69.8 & 63.7 \\
\hline Interorbital width & 24.3 & 22 & 19.9 & 26.9 & 22.9 \\
\hline Snout length & 49.6 & 22 & 42.2 & 50.2 & 46.8 \\
\hline Internarial length & 14.1 & 22 & 12.5 & 15.2 & 14.1 \\
\hline Anterior internarial width & 13.1 & 22 & 11.4 & 13.7 & 12.8 \\
\hline Posterior internarial width & 17.0 & 22 & 16.2 & 20.4 & 18.5 \\
\hline Horizontal eye diameter & 18.8 & 22 & 18.8 & 26.3 & 23.4 \\
\hline Mouth width & 31.8 & 22 & 29.7 & 34.2 & 32.0 \\
\hline Supraoccipital width & 19.5 & 22 & 17.4 & 22.4 & 19.5 \\
\hline Supraoccipital length & 38.5 & 22 & 35.4 & 42.2 & 38.3 \\
\hline
\end{tabular}

caudal fin. All mental barbels inserted in advance of gular fold apex, in a curved line parallel to mandibular margin. Tip of inner mental barbel sometimes reaching pectoral-fin base. Tip of outer mental barbel reaching tips edge middle pectoralfin rays, or almost edge of pectoral-fin spine. Posterior cleithral process broad, triangular, with ventral margin nearly straight, dorsal margin somewhat concave; granular and osseous tubercles on lateral surface. Urogenital papilla short, located in shallow depression immediately behind anus and between pelvic fins; its distal portion nearly triangular. No apparent sexual dimorphism. Dorsal fin II,6-7 (mode $=6 ; n=$ 26 ); its origin slightly anterior to vertical through tip of innermost pectoral-fin ray. Spinelet narrow, sharply angular, rounded in front; its tip gently rounded. Dorsal-fin spine straight, strong, pungent, and shorter than first branched ray; approximately as long as pectoral-fin spine length. Dorsal-fin spine bearing 1-3 dentations in its anterior and distal margin. Posterior margin of dorsal-fin spine with moderate sharp retrorse aculeus distally, becoming gradually smaller and erect proximally. First branched dorsal-fin ray longest, last dorsal-fin ray less than half length of first ray; distal margin of dorsal fin nearly straight. Adipose-fin origin at vertical through tip of outer pelvic-fin ray. Adipose-fin margin rounded and moderately deep, its apex short posterior to vertical through anal-fin origin, ending in short free lobe 
near vertical through tip of last anal-fin ray. Caudal fin deeply forked, with pointed lobes; dorsal lobe slightly longer than ventral lobe, its outer principal rays not filamentous. Dorsal lobe with 8 rays, 1 unbranched and 7 branched rays $(n=26)$; ventral lobe with 9-10 rays (mode $=9), 1$ unbranched and 89 branched rays $(n=26)$. Anal fin insertion on last third of standard length; without a distinct lobe in anterior portion of its margin; posterior margin concave; tips of longest anterior and posterior rays meeting when depressed. Analfin rays $12-15$ (mode $=14 ; \mathrm{n}=26), 4-6$ unbranched rays (mode $=5$ ) and 7-9 branched rays (mode $=8$ ); last ray unbranched, first and second branched rays longest. Pelvic fin, i,5 $(n=12)$, at or slightly anterior to vertical through end of dorsal-fin base; first branched ray longest. Pectoral fin I,9-10 (mode $=10 ; n=26)$; first soft ray approximately as long as pectoral-fin spine. Pectoral spine strong, pointed, dorsal and ventral surfaces smooth; numerous, regularly spaced, uniformly retrorse and simple dentations along most of posterior margin; antrorse and straight dentations along proximal half of anterior margin, becoming progressively less prominent and more concentrated proximally. Lateral line canal complete to caudal-fin base; declining to little ahead vertical through dorsal-fin origin, nearly straight from there to caudal-fin base; superficial tubular ossicles directed posteroventrally and more developed anteriorly; no accessory laterosensory canals posterior to nuchal area. Total vertebrae in four specimens, 40 (16 precaudals and 24 caudals). First pleural rib on 6th vertebra. Ten pairs of ribs.

Color in alcohol. Ground coloration of body grayish to yellowish, with three to six rows of dark spots regularly or irregularly scattered on sides of trunk. Number of rows of spots changes with body size - three or four rows in individuals smaller than $130.0 \mathrm{~mm} \mathrm{SL} \mathrm{(Fig.} \mathrm{2)} \mathrm{and} \mathrm{four} \mathrm{to} \mathrm{six}$ rows in larger individuals. Spots more abundant on anterior half of flanks; two to four rows of dark spots on posterior half of flanks. Dorsal surface of head with blackish spots; small dark brown spots on parietal and supraoccipital bones; several dark chromatophores on opercle and below orbit region. Ventral region of body light. All fins usually yellowish or dusky. Interradial membranes of dorsal fin hyaline, with scattered small black spots on its first half and dusky on the last. Adipose fin sometimes with two or three spots, with regularly scattered minute melanophores on its distal region. Caudal fin with few black melanophores on its interradial membranes and some black spots on dorsal lobe of some specimens (MZUSP 45208, 45465, 58711, and 79428), sometimes very faint. Ventral surface of maxillary barbel dusky. All mental barbels light to yellowish.

Variation. Two specimens (MZUSP 55479 and MZUSP 62886) from the rio Una da Aldeia, a tributary of rio Ribeira de Iguape, located just above of its mouth, and rio Una do Prelado, a small coastal river located just North of the mouth of the rio Ribeira de Iguape, respectively, possess ten to twelve rows of dark spots irregularly scattered on sides of trunk, whereas type specimens possess three to six rows of dark spots regularly or irregularly scattered on sides of trunk. Furthermore, the spots on non-type specimens are smaller when compared to type specimens, and the dorsal, adipose, and caudal fins are much more pigmented than those of types. The anal fin of the specimen from rio Una do Prelado is very spotted, while in specimens from rio Ribeira de Iguape basin, the anal fin is yellowish or dusky, spotless. These specimens were thus considered non-types, although no differences in morphometric or meristic features were found when compared with the specimens from rio Ribeira de Iguape.

Distribution. Rio Ribeira de Iguape basin, Ilha Comprida, and rio Una do Prelado (Fig. 3).

Etymology. From the Latin multi-, meaning many, numerous; cratis, from the Latin noun cratis, meaning rake, in reference to gill rakers; and fer from the Latin verb fero, meaning "to bear, carry, support, lift, hold, take up".

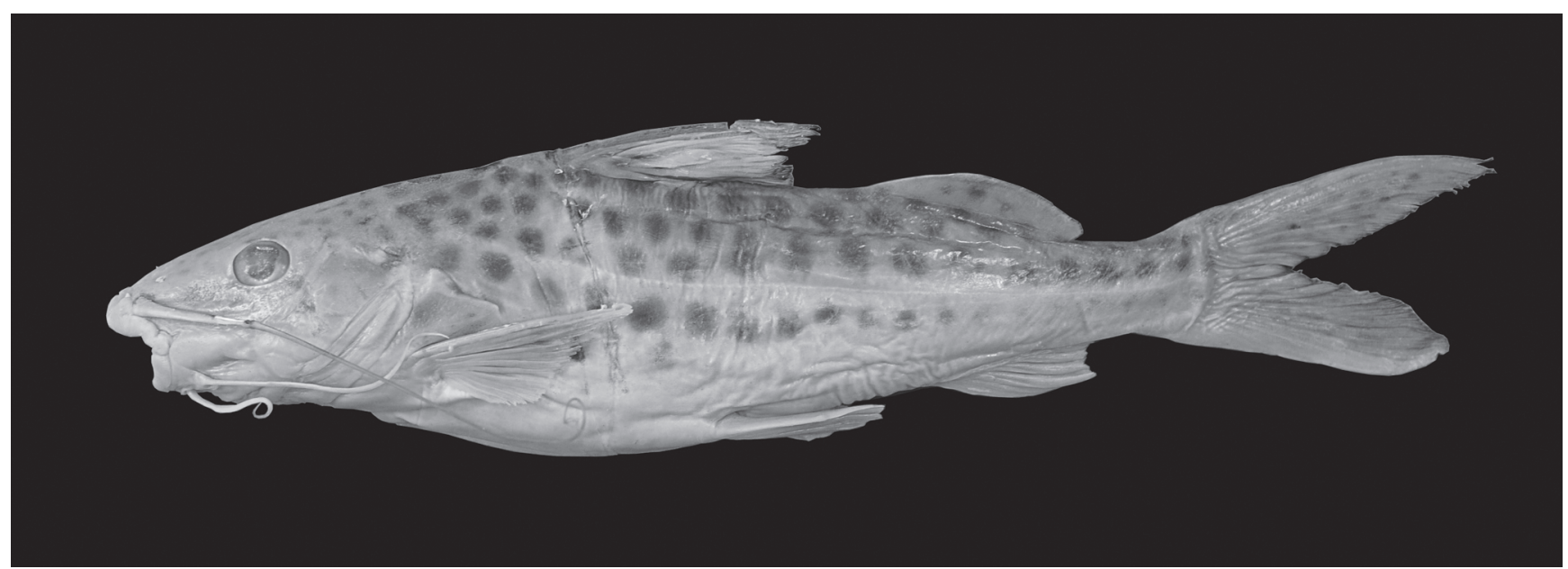

Fig. 2. Pimelodus multicratifer, paratype, MZUSP 45465, 118.6 mm SL, rio Pilões, rio Ribeira de Iguape basin, lateral view. 


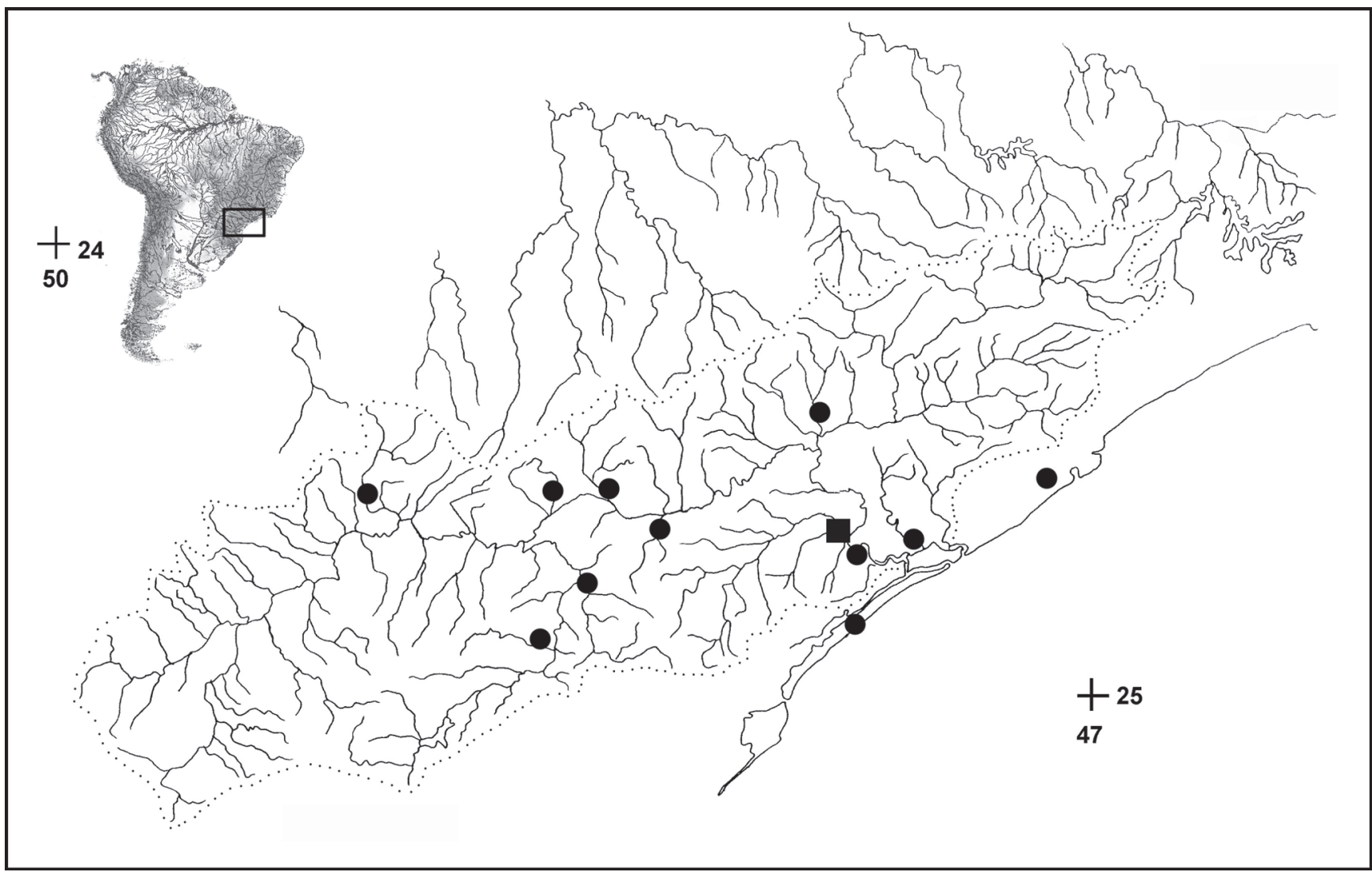

Fig. 3. Drainage map of the rio Ribeira de Iguape basin, showing geographic distribution of Pimelodus multicratifer. Type locality represented by square. Some symbols represent more than one lot of specimens.

Ecological notes. Pimelodus multicratifer is widely distributed throughout the rio Ribeira de Iguape drainage, ranging from the altitudes of $3 \mathrm{~m}$ above sea level at the rios Pariquera-Açu and Pariquera-Mirim in the lower strech of the rio Ribeira de Iguape, to $250 \mathrm{~m}$ above sea level at the rio Catas Altas in the high strech of the river basin. It was found mainly in the large rivers like Ribeira de Iguape, Catas Altas, Pariquera-Mirim and Turvo. The rivers of the high stretch have clear water running over rocks and sand; rivers of the low stretch have a turbid water, and in some case, acid black water like the rio Momuna, at the sandbank forest near the mouth of the rio Ribeira de Iguape into the sea. At the type locality, Pimelodus multicratifer occurs syntopically with the following species: Cyphocharax santacatarinae (Fernández-Yépez), Hoplias malabaricus (Bloch), Oligosarcus hepsetus (Cuvier), Hoplosternum littorale (Hancock) and Crenicichla iguapina Kullander \& Lucena.

Comments. Among the species formally described in the genus, the color pattern of specimens of Pimelodus pintado is similar to that of specimens of $P$. multicratifer. The analysis of a series of specimens of $P$. pintado showed that this species has two color patterns: (1) present in the holotype and in most larger specimens (see Azpelicueta et al., 2008: fig. 2A; MCP 43342, $160.0 \mathrm{~mm} \mathrm{SL}$ ), consisting of small dark spots forming 7-9 irregular horizontal rows on sides of trunk, and (2) consisting of larger dark spots forming 4-6 regular or irregular horizontal rows on sides of trunk. According to Azpelicueta et al. (2008), the latter pattern is usually present in young specimens and is related to ontogeny. This color pattern was also observed in large specimens of P. pintado (MCP21250,240.0 mm SL; MCP 23768, $208.0 \mathrm{~mm}$ SL). Despite the similarity in color of adults of the two species, the characters listed in the diagnosis are sufficient to distinguish them.

Comparative material. Pimelodus absconditus: Brazil: MCP 13392, 2, 129.3 and $133.7 \mathrm{~mm}$ SL, rio Uruguai; MCP 12515, 1, $125.0 \mathrm{~mm}$ SL, rio Uruguai. Pimelodus albicans: MCP 19248, 4, 139.9-199.6 mm SL, Argentina, rio Paraná. Pimelodus albofasciatus: RMNH 26156, holotype, PH, Suriname, rio Sipaliwini. Pimelodus altissimus: MZUSP 24588, 1, $148.9 \mathrm{~mm}$ SL, Brazil, rio Purus. Pimelodus cf. argenteus: MCP 15811, 4, 53.5-166.5 mm SL, Brazil, rio Paraguai. Pimelodus atrobrunneus: MCP 19678, holotype, $131.5 \mathrm{~mm}$ SL, Brazil, rio Uruguai. Pimelodus blochii: Brazil: MCP 20953, 1, 149.4 mm SL, rio Amazonas; MCP 23987, 11, 69.3-137.3 mm SL, rio Madeira; MZUSP 6394, 2, 72.9 and $182.8 \mathrm{~mm}$ SL, rio Purus; MZUSP 23555, 13, 56.5-91.7 mm SL, rio Japurá; MZUSP 34512, 8, 128.5$159.8 \mathrm{~mm}$ SL, rio Araguari; MZUSP 34513, 2, 151.3 and 154.0 $\mathrm{mm}$ SL, rio Xingu; MZUSP 50523, 3, 114.2-134.9 mm SL, rio Amazonas, rio Juruá; MZUSP 54558, 14, 75.1-117.4 mm SL, rio Tapajós; Peru: MCP 34506, 2, 69.1 and $101.7 \mathrm{~mm} \mathrm{SL}$, rio Amazonas, rio Pacaya. Pimelodus britskii: Brazil: MZUSP 50042, 15, not measured, rio Iguaçu; MZUSP 50043, 4, not measured, rio 
Iguaçu; MZUSP 50044, 11, not measured, rio Iguaçu. Pimelodus coprophagus: USNM 121150, holotype, PH, Venezuela, rio Agua Caliente. Pimelodus fur: Brazil: MCP 14051, 4, 84.8-111.3 mm SL, rio São Francisco; MCP 37328, 1, 123.2 mm SL, rio São Francisco; MZUSP 39643, 11, 58.7-105.9 mm SL, rio São Francisco; MZUSP 39643, 11, 59.5-105.9 mm SL, rio São Francisco; MZUSP 39143, 1, 89.4 mm SL, rio São Francisco. Pimelodus grosskopfii: NMW 45781-82, syntypes, PH, Colombia, rio Cauca. Pimelodus halisodous: MCP 41738, holotype, 108.8 mm SL, Brazil, rio Paranã, rio Tocantins. Pimelodus jivaro: Brazil: MZUSP 57672, 2, 90.9 and $92.5 \mathrm{~mm}$ SL, rio Trombetas. Pimelodus joannis: MCP 41739 , holotype, $51.0 \mathrm{~mm}$ SL, Brazil, Ipueiras, rio Tocantins. Pimelodus maculatus: Argentina: MCP 19249, 3, 56.7-102.0 mm SL, Argentina, rio Paraná; MZUSP 44776, 2, 82.9 and $128.2 \mathrm{~mm} \mathrm{SL}$, rio de La Plata. Brazil: MCP 13235, 1, 167.7 mm SL, rio Uruguai; MZUSP 1188, 1, $211.7 \mathrm{~mm}$ SL, rio Uruguai; MZUSP 24456, 1, $61.8 \mathrm{~mm}$ SL, ilha Solteira, rio Paraná; MZUSP 58655, 4, 128.5-200.1 mm SL, rio Paraná. Pimelodus microstoma: Brazil: NMW 45823, syntype, PH, Irisanga, rio Paraná; NMW 45824, 2 syntypes, 140.0 and 125.8 mm SL, Irisanga, rio Paraná; MZUSP 22713, holotype of Pimelodus heraldoi, PH, $179.0 \mathrm{~mm}$ SL, rio Paraná, rio Mogi Guaçu; MZUSP 22695, paratypes of Pimelodus heraldoi, 7, not measured, Pirassununga, rio Mogi Guaçu, Cachoeira de Emas; MZUSP 22696, paratypes, 18, 90.5-171.5 mm SL; rio Mogi Guaçu; MZUSP 38915, paratypes of Pimelodus heraldoi, 7, 104.6-116.1 mm SL, rio Paranaíba. Pimelodus mysteriosus: Argentina: MLP 9191, holotype, $103.0 \mathrm{~mm}$ SL, PH, Argentina, arroio Anselmo; Brazil: MZUSP 44403, paratype, not measured, rio Paraguay. Pimelodus navarroi: USNM 121174, holotype, PH, Venezuela, Lago Maracaibo. Pimelodus ornatus: Brazil: MCP 28870, 1, $90.7 \mathrm{~mm}$ SL, rio Purus; MCP 15898, 1, $152.7 \mathrm{~mm} \mathrm{SL}$, rio Tocantins. Pimelodus ortmanni: Brazil: FMNH 54240, holotype, $161.5 \mathrm{~mm}$ SL, PH, rio Iguaçu; MZUSP 50048, 6, 128.5-151.2 mm SL, rio Iguaçu; MZUSP 50053, 22, 115.2-170.1 mm SL, rio Iguaçu; MZUSP 50057, 27, 94.6-128.4 mm SL, rio Iguaçu. Pimelodus pantaneiro MZUSP 87808, 1, $228.0 \mathrm{~mm}$, Brazil, rio Miranda. Pimelodus paranaensis: Brazil: MZUSP 23089, holotype, 235.0 mm SL, rio Paraná; MZUSP 24454, 1, 121.4 mm SL, rio Paraná; MZUSP 28431, 1, 99.3 mm SL, rio Paraná; MZUSP 28432, 1, $71.1 \mathrm{~mm}$ SL, rio Paraná; MZUSP 28434, 1, $70.4 \mathrm{~mm} \mathrm{SL}$, rio Paraná. Pimelodus pictus: Brazil: MCP 29853, 1, 72.0 mm SL, rio Solimões; Peru: MZUSP 25976, 1, $67.4 \mathrm{~mm}$ SL, rio Ucayali. Pimelodus pintado: Uruguay: ZVC P 6482, holotype, PH, MerínPatos System, río Cebollatí; Brazil: MCP 8979, 1, 89.5 mm SL, c\&s, Taquara, rio Jucai; MCP 17654, 9, 105.0-202.0 mm SL, lago Guaíba; MCP 21250, 8, 116.0-234.0 mm SL, rio Jacuí, Arroio do Tigre; MCP 23768, 23, 112.9-208.0 mm SL, rio Jacuí; MCP 28087 , 15, 89.8-213.0 mm SL, rio Jacuí, delta of rio Jacuí; MCP 43342, 1, 160.0 mm SL, rio Jacuí; MZUSP 78452, 4, 87.8-125.5 mm SL, laguna dos Patos. Pimelodus platicirris: Brazil: AMNH 8628, 1, 190.0 mm SL, PH, rio Mogi Guaçu; MZUSP 22716, 76, 108.6$170.0 \mathrm{~mm}$ SL, rio Mogi Guaçu; MZUSP 79838, 26, 111.8-140.3 $\mathrm{mm}$ SL, rio Mogi Guaçu; MZUSP 58655, 4, 128.5-200.9, rio Mogi Guaçu. Pimelodus pohli: Brazil: MCP 16661, 6, 44.3-105.7 mm SL, rio São Francisco; MCP 16668, 4, 69.3-85.3 mm SL, rio São Francisco; MCP 16671, 7, 63.6-98.8 mm SL, rio São Francisco; MZUSP 24704, 2, 128.7 and $134.3 \mathrm{~mm} \mathrm{SL}$, rio São Francisco; MZUSP 39320, 6, 95.0-121.7 mm SL, rio São Francisco. Pimelodus punctatus: FMNH 7577, holotype, PH, Panamá. Pimelodus stewarti: MCP 41737, holotype, 54.1 mm SL, Brazil, rio Paranã, rio Tocantins. Pimelodus tetramerus MZUSP 85809, holotype, $112,9 \mathrm{~mm}$ SL, Brazil, rio Tocantins.

\section{Acknowledgements}

We thank José Lima de Figueiredo for the assistance dedicated to FRVR during his visit to MZUSP collection; Paulo H. F. Lucinda (UNT) for helpful with the formation of specific epithet of the new species; FRVR benefited from a CNPq/ Doctoral scholarship. Field trips were supported by Fundação de Amparo à Pesquisa do Estado de São Paulo (FAPESP) within the BIOTA/FAPESP - The Biodiversity Virtual Institute Program (www.biotasp.org.br); Project No. 00/04300-9, entitled "Diversidade de peixes de riachos e cabeceiras da Bacia do rio Ribeira de Iguape no Estado de São Paulo" coordinated by Osvaldo T. Oyakawa.

\section{Literature Cited}

Azpelicueta, M., J. G. Lundberg \& M. Loureiro. 2008. Pimelodus pintado (Siluriformes: Pimelodidae), a new species of catfish from affluent rivers of Laguna Merín, Uruguay, South America. Proceedings of the Academy of Natural Sciences of Philadelphia, 157: 149-162.

Costa, W. J. E. M., 2006. Taxonomy and phylogenetics relationships among species of the seasonal, internally inseminating, South American killifish genus Campellolebias (Teleostei: Cyprinodontiformes: Rivulidae) with the description of a new species. Zootaxa, 1227: 31-55.

Costa, W. J. E. M., S. M. Q. Lima \& C. R. Bizerril. 2004. Microcambeva ribeirae sp. n. (Teleostei: Siluriformes: Trichomycteridae): a new sarcoglanidine catfish from the Rio Ribeira do Iguape basin, southeastern Brazil. Zootaxa, 563: 1-10.

Dahl, G. 1961. Nematognathous fishes collected during the Macarena Expedition 1959. Part II: Pimelodidae, Callophysidae. Novedades Colombianas, 1(6): 483-514.

Eigenmann, C. H. \& R. S. Eigenmann. 1890. A revision of the South America Nematognathi or catfishes. Occasional Papers of the California Academy of Sciences, 1(2): 1-508.

Ferraris, C. J., Jr. 2007. Checklist of catfishes, recent and fossil (Osteichthyes: Siluriformes), and catalogue of siluriform primary types. Zootaxa, 1418: 1-628.

Lundberg, J. G., A. H. Bornbusch \& F. Mago-Leccia. 1991. Gladioglanis conquistador n. sp. from Ecuador with diagnoses of the subfamilies Rhamdiinae Bleeker and Pseudopimelodinae n. subf. (Siluriformes: Pimelodidae). Copeia, 1991: 190-209.

Lundberg, J. G. \& M. W. Littmann. 2003. Family Pimelodidae (Longwhiskered catfishes). Pp. 432-446.In: Reis, R. E., S. O. Kullander \& C. Ferraris Jr. (Eds.). 2003. Check List of the Freshwater Fishes of South and Central America. Porto Alegre, Edipucrs, 729p.

Lundberg, J. G. \& L. A. McDade. 1986. On the South American catfish Brachyrhamdia imitator Myers (Siluriformes, Pimelodidae), with phylogenetic evidence for a large intrafamilial lineage. Notulae Naturae, 463: 1-24.

Lundberg, J. G. \& B. M. Parisi. 2002. Propimelodus new genus, and redescription of Pimelodus eigenmanni Van der Stigchel 1946, a long-recognized yet poorly-known South American catfish (Pimelodidae: Siluriformes). Proceedings of the Academy of Natural Science, 152: 75-88.

Marini, T. L., J. T. Nichols \& F. R. La Monte. 1933. Six new eastern South American fishes examined in the American Museum of Natural History. American Museum Novitates, 618: 1-7. 
Ottoni, F. P., O. T. Oyakawa, W. J. E. M. Costa. 2008. A new species of the genus Australoheros from the rio Ribeira de Iguape basin, São Paulo, Brazil (Labroidei: Cichlidae: Cichlasominae). Vertebrate Zoology, 58: 75-81

Oyakawa, O. T., A. Akama, K. C. Mautari \& J. C. Nolasco. 2006. Peixes de Riachos da Mata Atlântica nas Unidades de Conservação do Vale do Ribeira de Iguape no Estado de São Paulo. São Paulo, Neotrópica, 201p.

Oyakawa, O. T., A. Akama, A. M. Zanata. 2005. Review of the genus Hypostomus Lacépède, 1803 from rio Ribeira de Iguape basin, with description of a new species (Pisces, Siluriformes, Loricariidae). Zootaxa, 921: 1-17.

Pereira, E. H. L. \& O. T. Oyakawa. 2003. Isbrueckerichthys epakmos, a new species of loricariid catfish from the rio Ribeira de Iguape Basin, Brazil (Teleostei: Siluriformes). Neotropical Ichthyology, 1(1): 3-9.
Ribeiro, F. R. V. \& C. A. S. Lucena. 2006. A new species of Pimelodus La Cépède, 1803 (Siluriformes, Pimelodidae) from the rio São Francisco drainage, Brazil. Neotropical Ichthyology, 4(4): 411418.

Takako,A. K., C. Oliveira \& O. T. Oyakawa. 2005. Revision of the genus Pseudotocinclus (Siluriformes: Loricariidae: Hypoptopomatinae), with descriptions of two new species. Neotropical Ichthyology, 3(4): 499-508.

Taylor, W. R. \& G. C. van Dyke. 1985. Revised procedures for staining and clearing small fishes and other vertebrates for bone and cartilage study. Cybium, 9: 107-119.

Wosiacki, W. B. \& O. T. Oyakawa. 2005. Two new species of catfish genus Trichomycterus (Siluriformes - Trichomycteridae) from the rio Ribeira de Iguape Basin, Southeastern Brazil. Neotropical Ichthyology, 3(4): 465-472.

Accepted September 29, 2010

Published March 31, 2011 